\title{
Variation rs9929218 and risk of the colorectal Cancer and adenomas: A meta- analysis
}

\author{
Huiyan Wang ${ }^{1 \dagger}$, Dongying $\mathrm{Gu}^{2 \dagger}$, Miao Yu${ }^{1}$, Yanjun $\mathrm{Hu}^{1}$, Zhe Chen ${ }^{1}$, Xinying Huo ${ }^{2}$, Tao Yu${ }^{1}$, Jinfei Chen ${ }^{2}$ and \\ Yang Zheng ${ }^{1 *}$
}

\begin{abstract}
Backgrounds: Genome-wide association studies (GWAS) have identified multiple common CRC-related (colorectal cancer) SNPs (single nucleotide polymorphisms) including the Cadherin 1(CDH1) rs9929218 may act by increasing the risk of colorectal cancer, colorectal adenoma, or both. These studies, however, reported inconsistent associations.

Methods: To derive a more accurate approximation of the connection, we carried out a meta-analysis of 12 published pieces of research including 11,590 controls and 8192 cases. We used odds ratios (ORs) and 95\% confidence intervals (Cls) to evaluate the associations' strength.
\end{abstract}

Results: Meta-analysis implied considerable association between CRC and rs9929218 (OR $=1.21,95 \% \mathrm{Cl}$ 1.04-1.42 for $G G$ versus $A A ; O R=1.22,95 \% \mathrm{Cl} 1.05-1.42$ for $G G / A G$ versus $A A)$. In the subgroup analyses, significantly increased risks were found among Europeans.

Conclusions: In summary, our meta-analysis studies in different populations confirmed that SNP rs9929218 is significantly associated with CRC risk and that this variant may have a greater impact on Europeans.

Keywords: Colorectal cancer, Adenomas, SNP, rs9929218, Meta-analysis

\section{Background}

More than one million people worldwide are affected by colorectal cancer (CRC) every year [1]. It is currently the third most frequent malignancy and the fourth commonest cause of cancer-related mortality in the world [2], and accounts for approximately 630,000 death from $\mathrm{CRC}$ annually. Previous genetic epidemiological studies provided evidence that CRC is a complex disease influenced by environmental and genetic factors and their interactions [3]. The majority of CRC are developed from

\footnotetext{
* Correspondence: 51833371@qq.com

†Huiyan Wang and Dongying Gu contributed equally to this work. 'Liaoning Cancer Hospital of China Medical University, Liaoning Cancer Hospital \& Institute, No.44 Xiaoheyan Road, Dadong District, Shenyang, Liaoning Province 110042, People's Republic of China

Full list of author information is available at the end of the article
}

colorectal adenomas (CRA) [4]. It is well-recognized that the high genetic risk of CRC is due in large part to the susceptibility to adenomas [5]. Single nucleotide polymorphism associated with CRC may increase the risk of colorectal cancer, colorectal adenomas, or both.

Genome-wide Association Studies (GWAS), effectively apply to multiple common single nucleotide polymorphisms (SNPs), and these SNPs have been illustrated to correlate with the individual susceptibility to CRC $[1,6-$ 8]. Various kinds of genetic loci associated with increased or decreased risk of colorectal cancer $(\mathrm{CRC})$ on 8q23.3, 8q24.21, 9p24, 10p14, 11q23.1, 14q22.2, 15q13.3, $16 \mathrm{q} 22.1,18 \mathrm{q} 21.1,19 \mathrm{q} 13.1$, and $20 \mathrm{p} 12.3$ have been

(c) The Author(s). 2021 Open Access This article is licensed under a Creative Commons Attribution 4.0 International License, which permits use, sharing, adaptation, distribution and reproduction in any medium or format, as long as you give appropriate credit to the original author(s) and the source, provide a link to the Creative Commons licence, and indicate if changes were made. The images or other third party material in this article are included in the article's Creative Commons licence, unless indicated otherwise in a credit line to the material. If material is not included in the article's Creative Commons licence and your intended use is not permitted by statutory regulation or exceeds the permitted use, you will need to obtain permission directly from the copyright holder. To view a copy of this licence, visit http://creativecommons.org/licenses/by/4.0/. The Creative Commons Public Domain Dedication waiver (http://creativecommons.org/publicdomain/zero/1.0/) applies to the data made available in this article, unless otherwise stated in a credit line to the data. 
identified by GWAS, illustrating, the CRC as a complex genetic disease [1, 6, 8-12].

Among these SNPs, rs9929218 (16p22.1), located in the intron region of the gene cadherin 1 (CDH1), was identified to be associated with CRC risk [13]. In 2016, Han et al. conducted a meta-analysis of rs9929218 including 16 studies $(n=131,768)$ which emphasizes a significant association between rs9929218 polymorphism and CRC susceptibility [13]. Nonetheless, its limitation is the absence of raw genotype data that reference dominant and recessive models.

The rs 9929218 has been identified as an aroused general interest for CRC susceptibility by recent genomewide association studies and this polymorphism has shown that the $G$ allele is associated with an increased risk of colorectal cancer. However, some of the literature has produced contrary results $[14,15]$.

We, therefore, performed a meta-analysis of the published studies to clarify this antilogy and constitute a comprehensive map of the relationship between 16q22.1 (rs9929218) polymorphism and the CRC susceptibility.

\section{Methods}

Our meta-analysis is reported followed the guideline of the PRISMA (Preferred Reporting Items for Systematic Review and Meta-Analysis) statement [16]. There are no ethical issues involved in our study because our data were based on published studies, and no ethical issues were involved in the selection, extraction and analysis of the data.

\section{Identification and eligibility of relevant studies}

Embase, PubMed, and ScienceDirect database were hunted invoking the semesters: 'rs9929218', 'Single Nucleotide Polymorphism ','colorectal cancer 'and 'colorectal adenoma 'to gather eligible articles. The combinations of following keywords were used: 'Neoplasms, Colorectal' or 'Colorectal Neoplasm' or 'Neoplasm, Colorectal' or 'Colorectal Tumors' or 'Colorectal Tumor' or 'Tumor, Colorectal' or 'Tumors, Colorectal' or 'Colorectal Carcinoma' or 'Carcinoma, Colorectal' or 'Carcinomas, Colorectal' or 'Colorectal Carcinomas' or 'Colorectal Cancer' or 'Cancer, Colorectal' or 'Cancers, Colorectal' or 'Colorectal Cancers'; 'Nucleotide Polymorphism, Single' or 'Nucleotide Polymorphisms, Single' or 'Polymorphisms, Single Nucleotide' or 'Single Nucleotide Polymorphisms' or 'SNPs' or 'Single Nucleotide Polymorphism'; 'rs9929218'.

We searched literature published before February 2020 and the language was restricted to English. This search was implemented by two students independently to determine potential publications meeting our inclusion criteria. If there is a clash, two students consult with the third reviewer and achieve a consensus [3, 17]. Studies in our meta-analysis ought to meet the following inclusion standards: (1) assess the association between colorectal cancer risk and the rs9929218 polymorphism; (2) the studies were designed as case-control studies; (3) include the detailed frequency of each genotype.

\section{Data extraction}

Two researchers appraised and extracted all data from all qualified publications independently, as reported by the inclusion standards that were listed above. The following data was gathered from each study: the name of the first author, the year of publication, the country of study, the specific number of genotypes in each control and case group; and the source of the control group (population- or hospital-based controls). Varying ethnic ancestries were classified as European, Asians, or Other including more than one ethnicity's subjects $[13,17]$. There is no duplicate sample was included in these 12 studies.

\section{Statistical analysis}

The strength of the association between the CRC risk and rs9929218 polymorphism was measured through odds ratios (ORs) with 95\% confidence intervals (CIs). The statistical significance of the pooled OR was determined using the Z-test [17]. First of all, we measured four genetic models: the homozygous model (GG vs. AA), the heterozygous model (GA vs. AA), the dominant model (GG + GA vs. AA), and the recessive model (GG vs. $\mathrm{GA}+\mathrm{AA}$ ) respectively (A: wild allele; G: mutated allele). Stratified analysis based on race, disease type, and source of control.

In return for the probability of heterogeneity throughout the researches, a statistical test for heterogeneity was performed based on the chi-square-based $\mathrm{Q}$ test $[17,18] . P<0.05$ was considered significant for the heterogeneity. We used two kinds of metaanalysis models including the Mantel-Haenszel (M-H) fixed-effect model and the DerSimonian-Laird (D-L) random-effect model to compute the pooled OR. With the proviso that no significant heterogeneity $\left(\mathrm{I}^{2}\right.$ is $50 \%$ or less) learnings involved in, the pooled OR is calculated by the fixed-effect model; otherwise $\left(\mathrm{I}^{2}\right.$ more than $75 \%$ ) the OR is calculated by the randomeffect model [17]. We did a sensitivity analysis to evaluate the stability of the results, one single study in the meta-analysis was excluded each time to report the influence of the respective data set to the pooled OR. We offer a potential publication bias with a funnel plot of diagnosis. All analyses were performed using STATA software (Stata Corporation, College Station, TX; version 12.0). 


\section{Results}

\section{Characteristics of studies}

Based on our inclusion criteria, we selected eligible articles from the PubMed, Embase, and Science Direct databases. Twelve eligible tests were included in the metaanalysis, involving data from 13 groups, including 6191 patients and 9314 controls associated with CRC and 2001 patients and 2276 controls associated with CRA
[14, 15, 19-25]. Genotype distribution was consistent with Hardy-Weinberg equilibrium in all controls studied $(P>0.05)$. The main characteristics of the study are shown in Fig. 1. And the raw data is in Table 1.

\section{Quantitative synthesis}

We computed the overall OR by the fixed effect model given no significant heterogeneity in all the selected

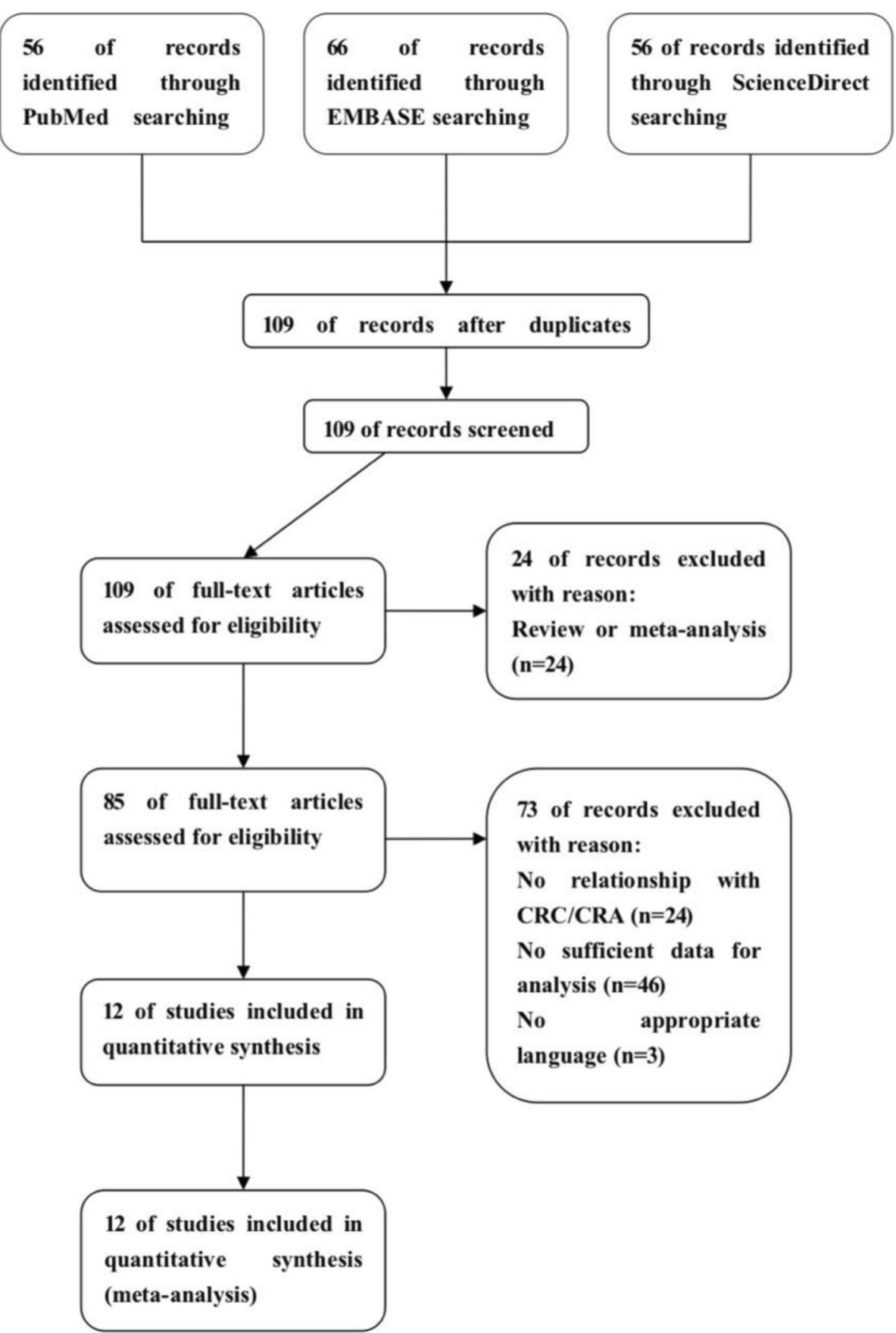

Fig. 1 Flow diagram of selection of studies included in the current meta-analysis for the association between rs9929218 polymorphism and CRC/ CRA. CRC, colorectal cancer. CRA, colorectal adenomas 
Table 1 Characteristics of studies included in the meta-analysis

\begin{tabular}{|c|c|c|c|c|c|c|c|c|c|c|c|}
\hline \multirow[t]{2}{*}{ Author } & \multirow[t]{2}{*}{ Year } & \multicolumn{3}{|c|}{ Case } & \multicolumn{3}{|c|}{ Control } & \multirow[t]{2}{*}{ Country } & \multirow[t]{2}{*}{ Ethnicity } & \multirow{2}{*}{$\begin{array}{l}\text { Source of } \\
\text { controls }\end{array}$} & \multirow[t]{2}{*}{ Type } \\
\hline & & $A A$ & AG & GG & $A A$ & AG & GG & & & & \\
\hline Vonholst & 2010 & 113 & 700 & 929 & 138 & 648 & 913 & Sweden & European & Mixed & CRC \\
\hline Rozadilla & 2010 & 65 & 345 & 435 & 83 & 342 & 459 & Spain & European & Hospital & CRC \\
\hline Ho & 2011 & 41 & 261 & 414 & 41 & 261 & 412 & China & Asian & Hospital & CRC \\
\hline Li & 2012 & 11 & 57 & 157 & 10 & 83 & 174 & China & Asian & Hospital & CRC \\
\hline Gira'ldez & 2012 & 10 & 82 & 99 & 108 & 496 & 652 & Spain & European & Population & CRC \\
\hline Win & 2013 & 52 & 144 & 216 & 49 & 183 & 257 & Mixed & Others & Mixed & CRC \\
\hline Yang & 2014 & 25 & 214 & 466 & 68 & 566 & 1168 & China & Asian & Population & CRC \\
\hline Hozyasz & 2014 & 22 & 102 & 126 & 48 & 222 & 270 & Poland & European & Population & CRC \\
\hline Burnett & 2014 & 31 & 183 & 275 & 66 & 321 & 394 & Seattle & Others & Hospital & CRA \\
\hline Abuli & 2016 & 97 & 523 & 706 & 101 & 514 & 651 & Spain & European & Hospital & CRA \\
\hline Ghorbanghli & 2016 & 12 & 86 & 88 & 22 & 98 & 109 & Holland & European & Population & CRA \\
\hline Abe & 2017 & 18 & 188 & 352 & 35 & 325 & 756 & Japan & Asian & Hospital & CRC \\
\hline Abe & 2017 & 16 & 145 & 386 & 16 & 172 & 359 & Japan & Asian & Hospital & CRC \\
\hline
\end{tabular}

CRC Colorectal cancer

CRA Colorectal adenomas

Table 2 Stratified analyses of the rs9929218 polymorphism on CRC/CRA risk

\begin{tabular}{|c|c|c|c|c|c|c|c|c|c|c|c|c|c|c|}
\hline \multirow[t]{2}{*}{ Variables } & \multirow[t]{2}{*}{$\mathrm{N}^{\mathrm{a}}$} & \multirow{2}{*}{$\begin{array}{l}\text { Case/ } \\
\text { Control }\end{array}$} & \multicolumn{3}{|l|}{ GG vs $A A$} & \multicolumn{3}{|l|}{$A G$ vs $A A$} & \multicolumn{3}{|c|}{ AG/GG vs $A A$} & \multicolumn{3}{|c|}{ GG vs $A A / A G$} \\
\hline & & & $\mathrm{OR}(95 \% \mathrm{Cl})$ & $P^{b}$ & $\mathrm{I}^{2}(\%)$ & OR(96\%Cl) & $P^{\mathbf{b}}$ & $\mathrm{I}^{2}(\%)$ & OR(97\%Cl) & $P^{b}$ & $I^{2}(\%)$ & OR(98\%Cl) & $P^{\mathbf{b}}$ & $\mathrm{I}^{2}(\%)$ \\
\hline Total & 13 & $\begin{array}{l}8192 / \\
11590\end{array}$ & $\begin{array}{l}1.14(1.00- \\
1.28)^{c}\end{array}$ & 0.042 & 0 & $\begin{array}{l}1.12(0.99- \\
1.27)\end{array}$ & 0.069 & 0 & $\begin{array}{l}1.13(1.00- \\
1.27)^{c}\end{array}$ & 0.044 & 0 & $\begin{array}{l}1.03(0.97- \\
1.09)\end{array}$ & 0.334 & 2.2 \\
\hline \multicolumn{15}{|l|}{ Disease type } \\
\hline CRC & 10 & $\begin{array}{l}6191 / \\
9314\end{array}$ & $\begin{array}{l}1.10(0.95- \\
1.27)\end{array}$ & 0.207 & 0 & $\begin{array}{l}1.11(0.95- \\
1.29)^{(1)}\end{array}$ & 0.201 & 6.8 & $\begin{array}{l}1.10(0.96- \\
1.27)\end{array}$ & 0.162 & 0 & $\begin{array}{l}1.00(0.94- \\
1.07)\end{array}$ & 0.909 & 0 \\
\hline CRA & 3 & $\begin{array}{l}2001 / \\
2276\end{array}$ & $\begin{array}{l}1.25(0.99- \\
1.58)\end{array}$ & 0.065 & 0 & $\begin{array}{l}1.15(0.90- \\
1.46)\end{array}$ & 0.267 & 0 & $\begin{array}{l}1.20(0.96- \\
1.52)\end{array}$ & 0.113 & 0 & $\begin{array}{l}1.12(0.99- \\
1.26)\end{array}$ & 0.075 & 0 \\
\hline \multicolumn{15}{|l|}{ Ethnicity } \\
\hline European & 6 & $\begin{array}{l}4540 / \\
5874\end{array}$ & $\begin{array}{l}1.21(1.04- \\
1.42)^{c}\end{array}$ & 0.016 & 0 & $\begin{array}{l}1.24(1.06- \\
1.45)^{c}\end{array}$ & 0.008 & 0 & $\begin{array}{l}1.22(1.05- \\
1.42)^{c}\end{array}$ & 0.010 & 0 & $\begin{array}{l}1.01(0.93- \\
1.10)\end{array}$ & 0.786 & 0 \\
\hline Asian & 5 & $\begin{array}{l}2751 / \\
4446\end{array}$ & $\begin{array}{l}1.00(0.78- \\
1.29)\end{array}$ & 0.996 & 0 & $\begin{array}{l}0.97(0.75- \\
1.26)\end{array}$ & 0.827 & 0 & $\begin{array}{l}0.99(0.77- \\
1.27)\end{array}$ & 0.945 & 0 & $\begin{array}{l}1.04(0.89- \\
1.20)\end{array}$ & 0.642 & 50.1 \\
\hline Other & 2 & $901 / 1270$ & $\begin{array}{l}1.08(0.58- \\
2.00)\end{array}$ & 0.806 & 74.3 & $\begin{array}{l}0.94(0.58- \\
1.53)\end{array}$ & 0.818 & 55.5 & $\begin{array}{l}1.02(0.58- \\
1.78)\end{array}$ & 0.945 & 70.6 & $\begin{array}{l}1.13(0.90- \\
1.43)\end{array}$ & 0.299 & 44.6 \\
\hline \multicolumn{15}{|c|}{ Source of controls } \\
\hline hospital & 7 & $\begin{array}{l}4706 / \\
5575\end{array}$ & $\begin{array}{l}1.13(0.96- \\
1.34)\end{array}$ & 0.141 & 0 & $\begin{array}{l}1.09(0.92- \\
1.30)\end{array}$ & 0.318 & 0 & $\begin{array}{l}1.12(0.95- \\
1.32)\end{array}$ & 0.181 & 0 & $\begin{array}{l}1.06(0.94- \\
1.19)\end{array}$ & 0.332 & 47.2 \\
\hline population & 4 & $\begin{array}{l}1332 / \\
3827\end{array}$ & $\begin{array}{l}1.20(0.90- \\
1.61)\end{array}$ & 0.213 & 0 & $\begin{array}{l}1.21(0.90- \\
1.63)\end{array}$ & 0.206 & 0 & $\begin{array}{l}1.21(0.91- \\
1.61)\end{array}$ & 0.190 & 0 & $\begin{array}{l}1.03(0.90- \\
1.17)\end{array}$ & 0.653 & 0 \\
\hline mixed & 2 & $\begin{array}{l}2154 / \\
2188\end{array}$ & $\begin{array}{l}1.03(0.66- \\
1.59)\end{array}$ & 0.910 & 67.3 & $\begin{array}{l}1.02(0.58- \\
1.79)\end{array}$ & 0.951 & 78.6 & $\begin{array}{l}1.02(0.62- \\
1.66)\end{array}$ & 0.941 & 75.4 & $\begin{array}{l}0.99(0.88- \\
1.11)\end{array}$ & 0.817 & 0 \\
\hline
\end{tabular}

a Number of comparisons

b $P$ value of Q-test for heterogeneity test

c Random-effects model was used when $P$ value for heterogeneity test $>0.05$; otherwise, fix-effects model was used

CRC Colorectal cancer

CRA Colorectal adenomas 


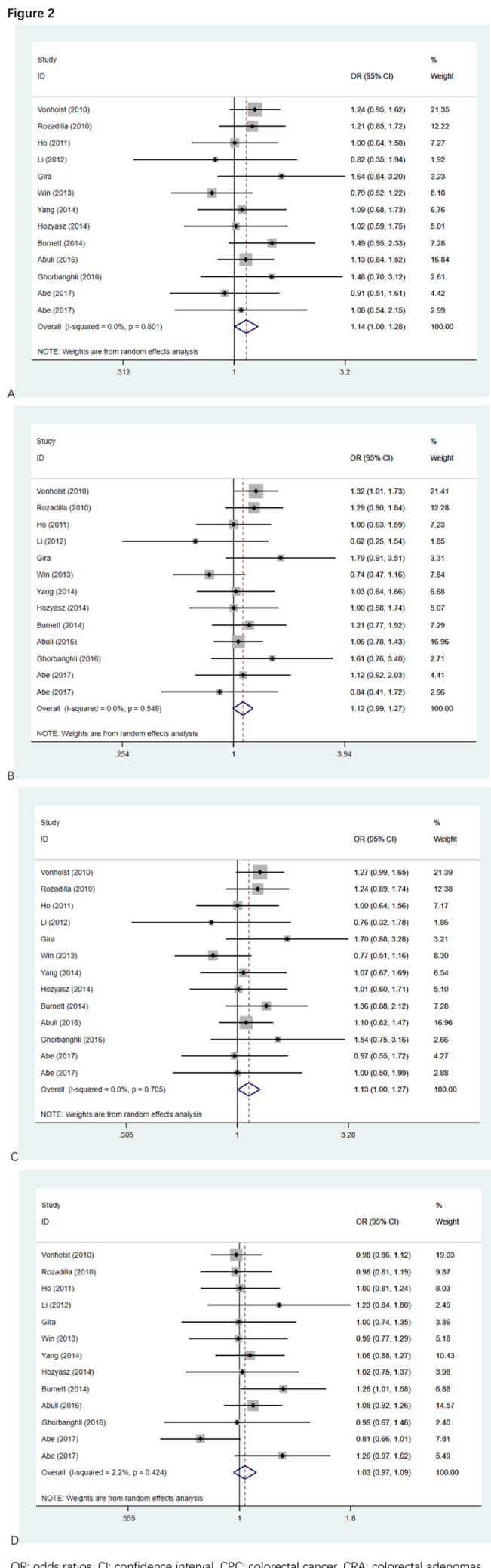

OR: odds ratios. Cl: confidence interval. CRC: colorectal cancer. CRA: colorectal adenomas
Fig. 2 Forest plots for the meta-analysis of rs9929218 polymorphism for overall using a random model. $\mathbf{a}$ the GG versus AA. $\mathbf{b}$ the GA versus $A A$. $\mathbf{c}$ the dominant model. $\mathbf{d}$ the recessive model. OR, odds ratios. $\mathrm{Cl}$, confidence interval. CRC, colorectal cancer. CRA, colorectal adenomas

studies. The main results of the meta-analysis for rs9929218 were listed in Table 2. For the increased risk of CRC and rs9929218 polymorphism, there was no significant evidence shows that the correlations were found between them when all eligible studies were integrated into the meta-analysis. As shown in the Fig. 2. For the rs9929218 polymorphism and CRC risk, our metaanalysis showed the general allele to that OR was 1.14 (95\% CI 1.00-1.28, $P=0.042$ ), and the relevant outcomes underneath the recessive and dominant genetic models were $1.13(95 \% \mathrm{CI} 1.00-1.27, P=0.044)$ and $1.03(95 \% \mathrm{CI}$ $0.97-1.9, P=0.334)$. Significant associations were consequently discovered for the dominant model and overall model.

A subgroup meta-analysis was further conducted by us in the type of disease, ethnicity, and the source of controls. As shown in the Fig. 3. In stratified by ethnic analysis, a significant association between rs9929218 is supported by the results of the European population and the CRC. In the subgroup analysis, GG genotypes were found to have a significantly higher risk $(O R=1)$ than AA genotypes in Europeans $(\mathrm{OR}=1.21,95 \% \mathrm{CI} 1.04-$ $1.42, P=0.016)$, AG versus AA genotype $(\mathrm{OR}=1.24$, $95 \% \mathrm{CI} 1.06-1.45, P=0.008)$ and $\mathrm{GG} / \mathrm{AG}$ versus AA genotype $(\mathrm{OR}=1.22,95 \% \mathrm{CI} 1.05-1.42, P=0.010)$. Such an association, however, was not obtained in Asian and the Others group. Considering the type of disease and the source of control, the significant association between risk and mutation in patients with CRC / CRA was not found, and there was no such correlation in each group of control groups.

\section{Test of heterogeneity}

According to the test for heterogeneity, there was no statistically significant heterogeneity in the overall comparison (Table 2) and therefore a fixed-effects model was conducted in this meta-analysis. Homozygous comparison (GG vs. AA: $P$ heterogeneity $=0.800, \mathrm{I}^{2}=0 \%$ ), heterozygote comparison (AG vs. AA: $\mathrm{P}$ heterogeneity = $0.548, \mathrm{I}^{2}=0 \%$ ), the dominant model comparison (GG/ $A G$ vs. AA:P heterogeneity $\left.=0.705, \mathrm{I}^{2}=0 \%\right)$ and the recessive model comparison (GG vs. AG/AA:P heterogeneity $=0.424, \mathrm{I}^{2}=0 \%$ ).

\section{Sensitivity analyses and publication bias}

We then evaluated the influence of each study on the combined OR by sequentially omitting each study and the outcomes suggested that none of the studies 


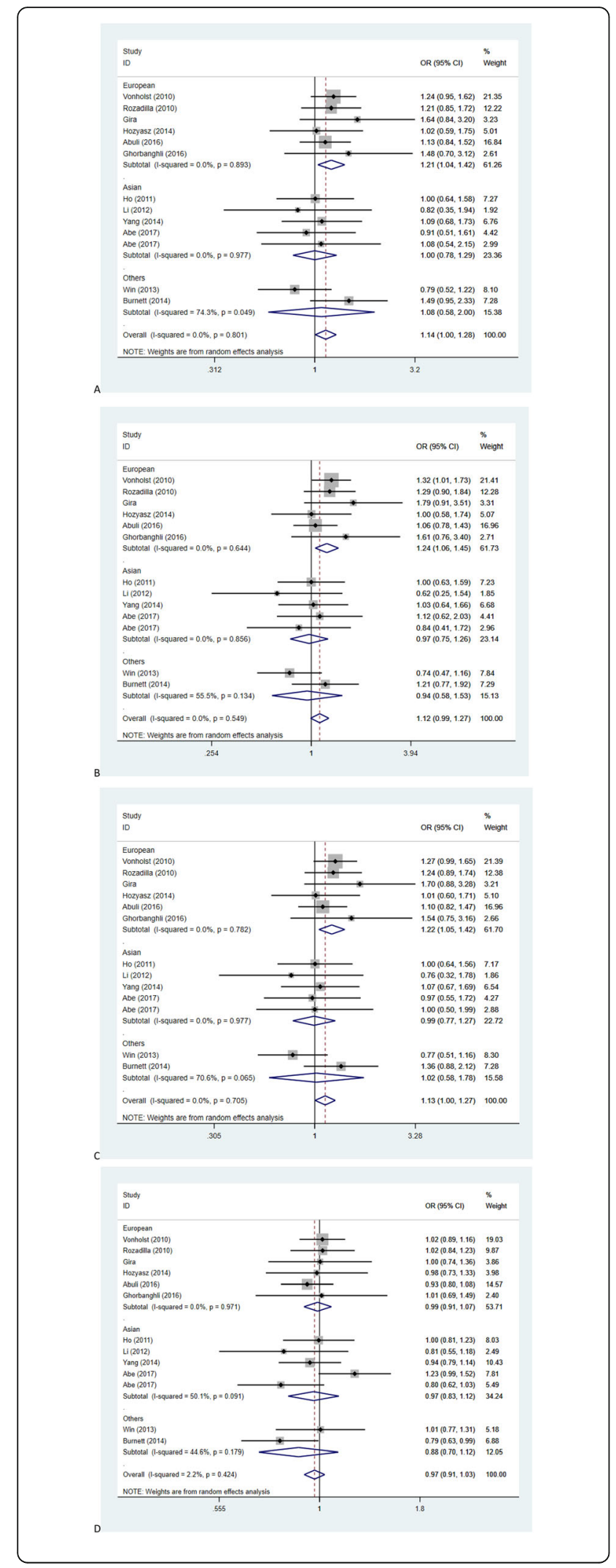

Fig. 3 Forest plots for the meta-analysis of rs9929218 polymorphism for ethnicity using a random model. $\mathbf{a}$ the GG versus AA. $\mathbf{b}$ the GA versus $A A$. $\mathbf{c}$ the dominant model. $\mathbf{d}$ the recessive model. OR, odds ratios. Cl, confidence interval. CRC, colorectal cancer. CRA, colorectal adenomas

meaningfully changed the pooled OR, indicating that the pooled OR of this polymorphism was robust. Perform funnel plots and Egger tests to estimate publication bias. As shown in Fig. 4, no significant asymmetry in the shape of the funnel plots was observed, indicating that no significant publication bias was presented in the study.

\section{Discussion}

CRC is one of the gastrointestinal cancers with a high degree of malignancy, aggressiveness, and rapid metastasis. The pathogenic factors of CRC are complicated, as other complex diseases, including both genes and the environment cause [3]. GWAS has different common single nucleotide polymorphism (SNP) associated with colorectal cancer risk. One of SNP with the strong association signal was rs9929218 at 16q22.1 [26, 27]. GWAS and replication studies conducted mostly in European populations but less in other ethnic populations.

Colorectal adenomas (CRA) is well-recognized premalignant lesions of CRC and the majority of CRC are formed from adenomas [3]. It has been reported that many genetic risks of CRC are partially mediated by susceptibility to adenomas. CRC-related SNPs may act by increasing the risk of CRC, CRA, or both [28]. CRA is a recognized precursor of CRC based on epidemiologic, histological, and genetic studies demonstrating shared genetic alterations. Several risk factors are related to the risk of developing CRA that is based on epidemiologic researches including cigarette smoking [29], alcohol intake [30], and obesity [31-34]. Siegert et al. observed significant interactions between alcohol consumption and rs9929218 [35]. In summary, we did a meta-analysis of the relationship between rs9929218 and increased susceptibility to CRC / CRA.

Rs9929218 is situated in the intron zone of CDH1, which encodes a calcium-dependent glycoprotein (Ecadherin). E-cadherin is encoded, a classical calcium adhesion protein, by The $\mathrm{CDH} 1$ gene essential for establishing and sustaining cell polarity, tissue constitution, and cell-to-cell adhesion. E-cadherin's low expression in CRC patients is connected with miserable prognoses, like invasive neoplasm development and metastasis in colorectal cancer [26, 36-38]. It is considered Ecadherin to be an important factor in epithelialmesenchymal transition (EMT), an important cellular program during tumor cell adhesion, migration, invasion, and metastasis [39]. The EMT is 


\section{Figure 4}

A

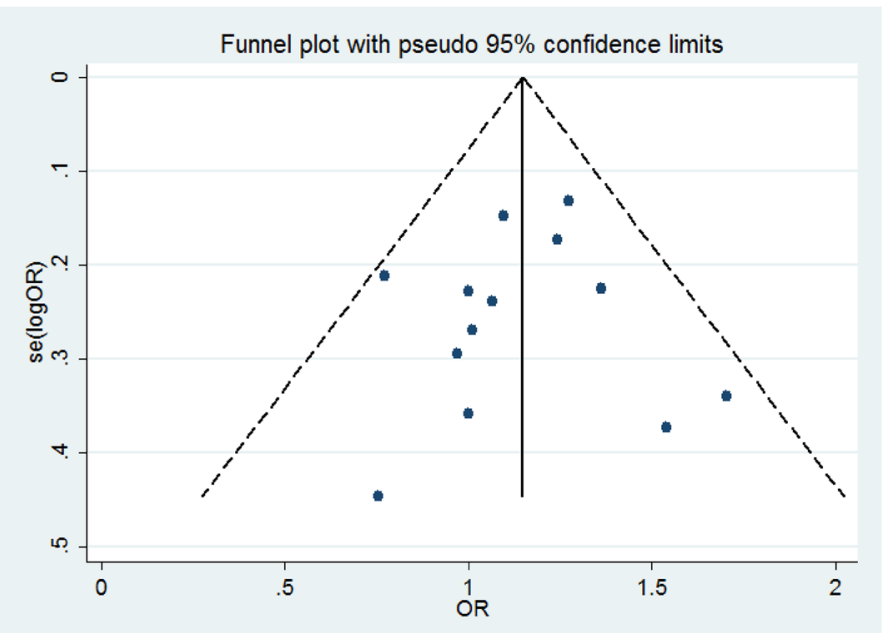

B

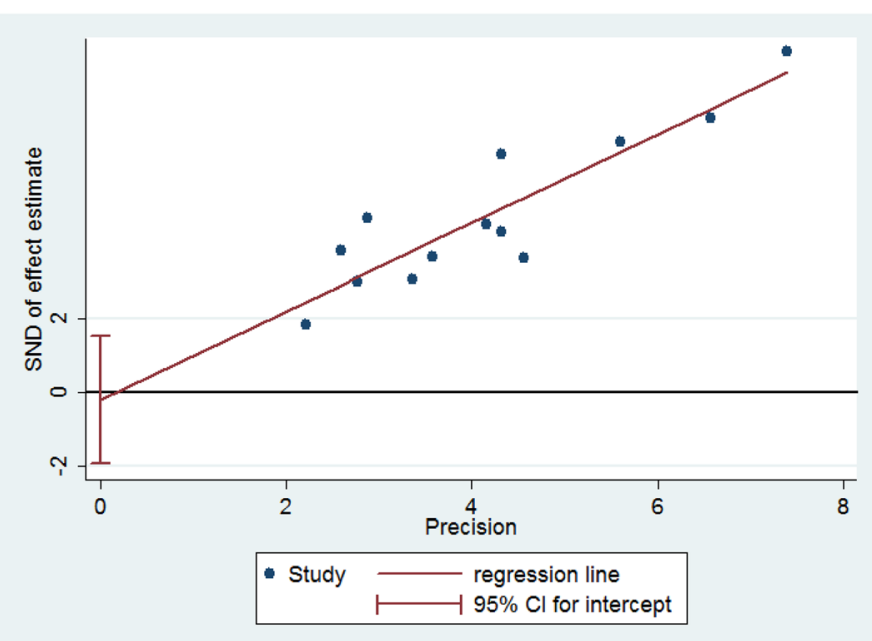

CI: confidence interval. SND: standard normal deviate.

C

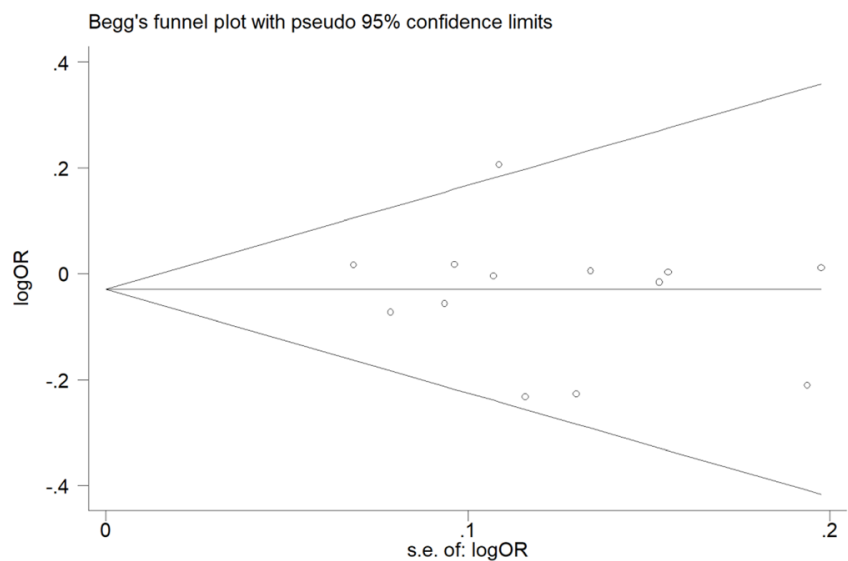

Fig. 4 Every point represents a separate study for the indicated association. Funnel plot (a) for publication bias analysis of the selected studies investigating the association between rs9929218 polymorphism and CRC/CRA. The X-axis stands for the ORs and the Y-axis is the standard error for each of the 12 studies. A linear regression based approach proposed by Egger test (b) and Begg plot (c) is used to evaluate the asymmetry of the funnel plot. Cl, confidence interval. SND, standard normal deviate 
suggested to be the first step in the metastatic of cancer cells by emerging evidence. Loss or reduction of E-cadherin expression is considered to be the primary and most important step in the EMT process, and EMT is a critical step in cancer metastasis $[39,40]$.

Our meta-analysis involved 12 studies, 13 groups of data, including 8192 cases and 11,590 controls. The combined results demonstrated that the rs 9929218 polymorphism was an increased risk factor for CRC in European populations and there was no significant heterogeneity throughout the study. Moreover, sensitivity analysis and publication bias suggest that our results are robust.

When stratified by ethnicity, significant associations between rs9929218 polymorphism and increased incidence of CRC were observed in Europeans. No clear association, however, was observed between Asia and other races in all genetic models, indicating that the conceivable causes are distinctions in habitat and genetic backgrounds. Besides, apart from genetic factors, multiple lifestyles for varying ethnic groups ought to also be reckoned for CRC risk.

Our meta-analysis's limitations should be regarded in the interpretation of the consequences. Firstly, the number of our case-control study enrolled in our analysis was insufficient. Secondly, we have collected only English literature in this meta-analysis. Thirdly, the involved ethnicities were limited (only Asian, European, and Other population) and further studies of larger sample sizes were needed to explore the influences of different ethnicities. Eventually, this study did not write about some of the potential factors such as age, sex, smoking, alcohol intake, lifestyles, and environmental factors.

\section{Conclusion}

In summary, our meta-analysis studies in different populations confirmed that SNP rs9929218 is significantly associated with CRC risk and that this variant may have a greater impact on Europeans than Asians and Others. Due to the limited research available on the current non-European population, further research is needed, including a broader range of population areas and themes. Furthermore, gene-environment interactions and genegene must also be reckoned in succeeding research.

\section{Abbreviations}

GWAS: Genome-wide association studies; SNPS: Single nucleotide polymorphisms; CRC: Colorectal cancer; CRA: Colorectal adenomas; $\mathrm{CDH1}$ : Cadherin 1; ORs: Odds ratios; Cls: Confidence intervals;

Cadherin: Calcium-dependent glycoprotein; EMT: Epithelial-mesenchymal transition; PRISMA: Preferred reporting items for systematic review and metaanalysis

Acknowledgements

Not applicable.

\section{Authors' contributions}

HW collected data and performed statistical analysis and was a major contributor in writing the manuscript. DG collected data and performed statistical analysis and was another major contributor in writing the manuscript. MY performed a data check. YH also verified the data. ZC also conducted a statistical analysis. XH checked the results of the statistical analysis. TY has organized the figures and Tables. JC reviewed the entire text. $Y Z$ reviewed the article and approved it for publication. All authors read and approved the final manuscript.

\section{Funding}

Not applicable.

\section{Availability of data and materials}

The datasets generated and analysed during the current study are available in the Embase, PubMed, and ScienceDirect repository, https://pubmed.ncbi. nlm.nih.gov/; https://www.embase.com; https://www.sciencedirect.com.

Ethics approval and consent to participate

Not applicable.

Consent for publication

Not applicable.

\section{Competing interests}

The authors declare that they have no competing interests.

\section{Author details \\ ${ }^{1}$ Liaoning Cancer Hospital of China Medical University, Liaoning Cancer Hospital \& Institute, No.44 Xiaoheyan Road, Dadong District, Shenyang, Liaoning Province 110042, People's Republic of China. ${ }^{2}$ Department of Oncology, The Affifiliated Nanjing First Hospital, Nanjing Medical University, 68 Changle Road, Nanjing, People's Republic of China.}

Received: 30 August 2020 Accepted: 2 February 2021

Published online: 24 February 2021

\section{References}

1. Tenesa A, Farrington SM, Prendergast JG, Porteous ME, Walker M, Haq N, et al. Genome-wide association scan identifies a colorectal cancer susceptibility locus on $11 \mathrm{q} 23$ and replicates risk loci at $8 \mathrm{q} 24$ and 18q21. Nat Genet. 2008;40:631-7.

2. World Health Organization. In: Stewart BW, Kleihues P, editors. World cancer report 13. Lyon, France: IARC; 2003.

3. Wang YP, Zhang J, Zhu HY. Common variation rs6983267 at 8q24.1 and risk of colorectal adenoma and cancer: evidence based on 31 studies. Tumor Biol. 2014:35:4067-75.

4. Tanaka T. Colorectal carcinogenesis: review of human and experimental animal studies. J Carcinog. 2009:8:5.

5. Carvajal-Carmona LG, Zauber AG, Jones AM, Howarth K, Wang J, Cheng T, Riddell R, Lanas A, Morton D, Bertagnolli MM, Tomlinson I. Much of the genetic risk of colorectal cancer is likely to be mediated through susceptibility to adenomas. Gastroenterology. 2013;144:53-5.

6. Houlston RS, Webb E, Broderick P, Pittman AM, Di Bernardo MC. Metaanalysis of genome-wide association data identifies four new susceptibility loci for colorectal cancer. Nat Genet. 2008;40:1426-35.

7. Zanke BW, Greenwood CM, Rangrej J, Kustra R, Tenesa A. Genome-wide association scan identifies a colorectal cancer susceptibility locus on chromosome 8q24. Nat Genet. 2007;39:989-94.

8. Tomlinson IP, Webb E, Carvajal-Carmona L, Broderick P, Howarth K. A genome-wide association study identifies colorectal cancer susceptibility loci on chromosomes 10p14 and 8q23.3. Nat Genet. 2008:40:623-30.

9. Broderick P, Carvajal-Carmona L, Pittman AM, et al. A genome-wide association study shows that common alleles of SMAD7 influence colorectal cancer risk. Nat Genet. 2007:39:1315-7.

10. Haiman CA, Le Marchand L, Yamamato J, et al. A common genetic risk factor for colorectal and prostate cancer. Nat Genet. 2007:39:954-6.

11. Tomlinson I, Webb E, Carvajal-Carmona L, Broderick P, Kemp Z, et al. A genome-wide association scan of tag SNPs identifies a susceptibility variant for colorectal cancer at 8q24.21. Nat Genet. 2007;39:984-8. 
12. Jaeger E, Webb E, Howarth K, Carvajal-Carmona L, Rowan A, Broderick P, et al. Common genetic variants at the CRAC1 (HMPS) locus on chromosome 15q13.3 influence colorectal cancer risk. Nat Genet. 2008;40: 26-8.

13. Han P, Liu G, Lu X, et al. CDH1 rs9929218 variant at 16q22.1 contributes to colorectal cancer susceptibility. Oncotarget. 2016;7(30):47278-86.

14. Li FX, Yang XX, Hu NY, Du HY, Ma Q, Li M. Single-nucleotide polymorphism associations for colorectal cancer in southern chinese population. Chin J Cancer Res. 2012;24:29-35.

15. Win AK, Hopper JL, Buchanan DD, Young JP, Tenesa A, Dowty JG, Giles GG, Goldblatt J, Winship I, Boussioutas A, Young GP, Parry S, Baron JA, et al. Are the common genetic variants assoiacted with colorectal cancer risk for DNA mismatch repair gene mutation carriers? Eur J Cancer. 2013;49:1578-87.

16. Moher D, Liberati A, Tetzlaff J, Altman DG, The PRISMA Group. Preferred reporting items for systematic reviews and meta-analyses: the PRISMA statement. PLoS Med. 2009;6(7):e1000097. https://doi.org/10.1371/journal. pmed1000097.

17. Gu DY, Wang ML, Wang MM, Zhang ZD, Chen JF. The DNA repair gene APE1 T1349G polymorphism and cancer risk: a meta-analysis of 27 casecontrol studies. Mutagenesis. 2009;24(6):507-12.

18. Handoll HH. Systematic reviews on rehabilitation interventions. Arch Phys Med Rehabil. 2006:87:875.

19. von Holst S, Picelli S, Edler D, Lenander C, Dalen J, Hjern F, Lundqvist N, Lindforss U, Pahlman L, Smedh K, Tornqvist A, Holm J, Janson M, et al. Association studies on 11 published colorectal cancer risk loci. Br J Cancer. 2010;103:575-80.

20. Fernández-Rozadilla C. Single nucleotide polymorphisms in the wnt and bmp pathways and colorectal cancer risk in a spanish cohort. PLoS One. 2010;5(9):1-9.

21. Ho JW, Choi SC, Lee YF, Hui TC, Cherny SS, Garcia-Barcelo MM, CarvajalCarmona L, Liu R, To SH, Yau TK, Chung CC, Yau CC, Hui SM, et al. Replication study of SNP associations for colorectal cancer in Hong Kong Chinese. Br J Cancer. 2011;104:369-75.

22. Giráldez M, López-Dóriga D, Bujanda A, Abulí L, Bessa A, FernandezRozadilla X, C. Susceptibility genetic variants associated with early-onset colorectal cancer. Gastroenterology. 2012;142(5):S510.

23. Yang $C Y L$, Lin $R H$, Jen $C H$, Tung $C H$, Yang $C Y$, Lin $S H$, Jiang JK, Lin JK, CH. Single nucleotide polymorphisms associated with colorectal cancer susceptibility and loss of heterozygosity in a Taiwanese population. PLoS One. 2014;9(6):e100060.

24. Hozyasz KK, Mostowska A, Wójcicki P, Lasota A, Offert B, Balcerek A, DuninWilczyńska I, Jagodziński PP. Nucleotide variants of the cancer predisposing gene $\mathrm{CDH} 1$ and the risk of non-syndromic cleft lip with or without cleft palate. Familial Cancer. 2014;13(3):415-21.

25. Abe M, Ito H, Oze I, Nomura M, Ogawa Y, Matsuo K. The more from eastAsian, the better: risk prediction of colorectal cancer risk by GWAS-identified SNPs among Japanese. J Cancer Res Clin Oncol. 2017;143(12):2481-92.

26. Smith CG, Fisher D, Harris R, et al. Analyses of 7,635 patients with colorectal cancer using independent training and validation cohorts show that rs9929218 in CDH1 is a prognostic marker of survival. Clin Cancer Res. 2015; 21(15):3453-61.

27. Ghazi S, von Holst S, Picelli S, Lindforss U, Tenesa A, Farrington SM, Campbell H, Dunlop MG, Papadogiannakis N, Lindblom A. Colorectal cancer susceptibility loci in a population-based study: associations with morphological parameters. Am J Pathol. 2010;177(6):2688-93.

28. Montazeri Z, Theodoratou E, Nyiraneza C. Systematic meta-analyses and field synopsis of genetic association studies in colorectal adenomas. Int J Epidemiol. 2016;45:186-205.

29. Botteri E, lodice S, Raimondi S, Maisonneuve P, Lowenfels AB. Cigarette smoking and adenomatous polyps: a meta-analysis. Gastroenterology. 2008; 134:388-95.

30. Zhu JZ, Wang YM, Zhou QY, Zhu KF, Yu CH, Li YM. Systematic review with meta-analysis: alcohol consumption and the risk of colorectal adenoma. Aliment Pharmacol Ther. 2014;40:325-37.

31. Ben $Q, A n W$, Jiang $Y$, et al. Body mass index increases risk for colorectal adenomas based on meta-analysis. Gastroenterology. 2012;142:762-72.

32. Hong S, Cai Q, Chen D, Zhu W, Huang W, Li Z. Abdominal obesity and the risk of colorectal adenoma: a meta-analysis of observational studies. Eur J Cancer Prev. 2012;21:523-31.
33. Okabayashi $\mathrm{K}$, Ashrafian $\mathrm{H}$, Hasegawa $\mathrm{H}$, et al. Body mass index category as a risk factor for colorectal adenomas: a systematic review and meta-analysis. Am J Gastroenterol. 2012;107:1175,85 quiz 1186.

34. Omata F, Deshpande GA, Ohde S, Mine T, Fukui T. The association between obesity and colorectal adenoma: systematic review and meta-analysis. Scand J Gastroenterol. 2013;48:136-46.

35. Siegert S, Hampe J, Schafmayer, C. Von Schönfels, W. Egberts, J. H. Försti, A. Chen, B. Genome-wide investigation of gene-environment interactions in colorectal cancer. Hum Genet. 2013;132(2):219-31.

36. Gargallo CJ, Lanas Á, Carrera-Lasfuentes P, Ferrandez Á, Quintero E, Carrillo M, Alonso-Abreu I, García-Gonzalez MA. Genetic susceptibility in the development of colorectal adenomas according to family history of colorectal cancer. Int J Cancer. 2019;144(3):489-502.

37. Song N, Kim K, Shin AP, Chang JW, Shi HJ, Cai J, Kim Q, Zheng DY, Oh W, $\mathrm{JH}$. Colorectal cancer susceptibility loci and influence on survival. Genes Chromosomes Cancer. 2018;57(12):630-7.

38. Peter G Vaughan-Shaw, Graeme Grimes, Anna-Maria Ochocka, Karen Dunbar, Maria Timofeeva, Fahrat V N Din, Susan M Farrington, Malcolm G Dunlop. "Investigation of gene-environment interactions between vitamin $\mathrm{D}$ and colorectal cancer susceptibility genetic variants in large bowel epithelium." Lancet; Volume 387, Special Issue, S102, February 25, 2016.

39. Huang CY, Hsieh MJ, Liu TC, Chiang WL, Liu MC, Yang SF, Tsao TCY. Correlation of E-cadherin gene polymorphisms and epidermal growth factor receptor mutation in lung adenocarcinoma. Int J Med Sci. 2018;15(8):76570

40. Sousa-Squiavinato ACM, Rocha MR, Barcellos-de-Souza, de Souza P, Fernandes W. Cofilin-1 signaling mediates epithelial-mesenchymal transition by promoting actin cytoskeleton reorganization and cell-cell adhesion regulation in colorectal cancer cells. Biochim Biophys ActaMol Cell Res. 2019;1866(3):418-29

\section{Publisher's Note}

Springer Nature remains neutral with regard to jurisdictional claims in published maps and institutional affiliations.

\section{Ready to submit your research? Choose BMC and benefit from:}

- fast, convenient online submission

- thorough peer review by experienced researchers in your field

- rapid publication on acceptance

- support for research data, including large and complex data types

- gold Open Access which fosters wider collaboration and increased citations

- maximum visibility for your research: over $100 \mathrm{M}$ website views per year

At BMC, research is always in progress.

Learn more biomedcentral.com/submissions 